\title{
ДУШАТА НА ЕДИН НАРОД: БЪЛГАРСКИЯТ НАЦИОНАЛЕН КАЛЕНДАР ОТ 1878 ГОДИНА ДО НАШИ ДНИ
}

\author{
Св. Елдъров
}

Елдъров Св. Душата на един народ: Българският национален календар от 1878 година до наши дни. Отличителна характеристика на Българския национален календар, разбиран като официална празнично-обредна система, е неговата непостоянност и променливост. В него се различават няколко периода. При управлението на княз Александър (1879-1886 г.) той се заражда и развива под силно руско влияние. Княз Фердинанд насърчава процеса на национализация, започнал със Съединението и Сръбско-българската война през 1885 г. Във военните години 1912-1918 на преден план изпъква бойният празник на Българската армия. В периода между двете световни войни официалните и неофициалните празници носят ярка национална символика и се стремят да изтъкнат приемствеността между възрожденските ценности и националните идеали. След 9 септември 1944 г. Българската комунистическа партия използва всички ресурси на тоталитарната държава, за да изтрие спомена от празничната система на предишната епоха, а официалният календар е подложен на интензивна съветизация. В годините на прехода след 10 ноември 1989 г. започва възстановяване на традиционните празници от периода преди Втората световна война. Въпреки това публичните дебати по въпроса за празниците от Българския национален календар все още продължават.

Ключови думи: Български национален календар, официални празници, политика, история.

Элдыров Св. Душа одного народа: Болгарский национальный календарь с 1878 года до наших дней. Отличительной характеристикой Болгарского национального календаря, понимаемого как празднично-обрядная система, является его непостоянность и изменчивость. В нем различают несколько периодов. Во времена правления князя Александра (1879-1886 гг.) он зарождается и развивается под сильным русским влиянием. Князь (с 1908 г. - царь) Фердинанд (1887-1918 гг.) поощряет процесс национализации, начавшийся с Соединения и сербо-болгарской войны 1885 года. В военные 1912-1918 годы на переднем плане выделяется боевой праздник Болгарской армии. В период между двумя мировыми войнами официальные и неофициальные праздники носят яркую национальную символику и стремятся подчеркнуть преемственность между ценностями эпохи болгарского Возрождения и национальными идеалами. После 9 сентября 1944 года Болгарская коммунистическая партия использовала все ресурсы тоталитарного государства, чтобы стереть воспоминания праздничной системы предыдущей эпохи, а официальный календарь был подвергнут интенсивной советизации. В годы перехода после 10 ноября 1989 года начинается восстановление традиционных праздников периода до Второй мировой войны. Но, несмотря на это, публичные дебаты по вопросу о праздниках Болгарского национального календаря все еще продолжаются.

Ключевые слова: Болгарский национальный календарь, официальные праздники, политика, история.

Eldarov Sv. The Soul of a Nation: Bulgarian National Calendar from 1878 to Nowadays. An essential characteristic of the Bulgarian National Calendar as representation of the Bulgarian official holidayritual system is its inconsistency and mutability. In it, several periods may be outlined. Its origins date from the rule of prince Aleksander (1879-1886) during which it developed under strong Russian influence. Prince (1908 - tzar/king) Ferdinand (1887-1918) encouraged the process of its acquiring greater national identity, which started with the Unification and the Serbian-Bulgarian War of 1885. During the war years between 1912-1918, the War Holiday of the Bulgarian Army came to the fore. During the period between World War I and World War II, the official and non-official holidays embedded clear national symbols and aimed to emphasize on the continuity between the National Revival values and the national ideals. After September 9, 1944 the Bulgarian Communist Party availed of all totalitarian State resources to obliterate the memory of the holiday system of the previous epoch, and the official calendar was subject to intensive designing after the Soviet manner. During the years of transition after November 10, 1989 restoration of the traditional holidays from the period preceding World War II was initiated. Nevertheless, the public debates concerning the holidays on the Bulgarian National Calendar are still ongoing.

Keywords: Bulgarian National Calendar, official holidays, politics, history.

Като система за измерване на времето, базирана на движението на небесните тела, периодичността на природните явления и последователността на годишните сезони, астрономическият календар отразява историческия опит на човечеството да намери своето място в динамиката на миналото, настоящето и бъдещето. Погледнат от този зрителен

(C) Елдъров, Св., 2016 
ьгъл, националният календар, основан на историческото развитие, религиозното вярване и културната традиция, отразява колективно осъзнатия и институционализиран стремеж на съответния народ, превърнал се в национална общност, да намери и отстои собствения си облик в една постоянно променяща се политическа динамика. Затова, когато в дни на национални чествания и юбилейни празненства в България (а и в други страни със сходна историческа и политическа съдба) се говори или пише за датите от националния календар, най-често използваните думи са „традиции“, „стожери“ или „опори“, които крепят народната памет и подхранват националната гордост. Един обективен научен поглед обаче няма как да не открие, че зад фасадата на празника се крие различната и прозаичната истина на делника. Ако има нещо, което най-точно да характеризира Българския национален календар, разбиран като официална празнично-обредна система, това е неговата непостоянност и променливост, която от своя страна е достоверно отражение на подемно-катастрофичния и етапно-преходния характер на българското историческо битие. Всеки сравнително обособен период от новата и най-новата история на България внася такива обновления и промени в националния календар, които трудно могат да се съвместят с дефинициите на традицията и приемствеността. Достатъчно е да се припомни, че в последния четвърт век от българската история, все още назоваван преход, един от най-продължителните и страстни публични дебати си остава този за националния ни празник. И ако е вярно, че националният календар най-точно разкрива душата на народа, ще трябва да признаем, че българският народ все още търси своята истинска душа.

Настоящата студия обобщава изследователските дирения на автора в последните десетина години за съдбата на различни празници от Българския национален календар и си поставя за цел да предостави обективен фактически материал за народопсихологически анализи на онези, които биха искали и биха могли да ги направят.

Официалният календар на българската държава се оформя в първите години след Освобождението (от османско иго) на основата на установената народна традиция и чуждия опит. В него се открояват три групи празници - църковни, династични и политически. Първият официален списък на празничните дни е приет от Държавния съвет на 12 октомври 1882 г., утвърден с указ № 766 на княз Александър I от 27 с.м. и обнародван в „Дьржавен вестник“ на 13 ноември с.г. Този документ предвижда общо 28 празнични или „неприсъствени“ дни, освен всички неделни дни в годината'․

Тъй като източноправославното християнство е изповядвано от мнозинството българи и е „господстващо“ по конституция, най-важните празници от неговия календарен цикъл закономерно попадат и в държавния календар. Това са: 6 януари - Богоявление Господне (Йордановден), 2 февруари - Сретение Господне, 25 март - Благовещение, 23 април Св. Георги Победоносец (Гергьовден), 11 май - Св. св. Кирил и Методий, 29 юни - Св. св. Петьр и Павел (Петровден), 6 август - Преображение Господне, 15 август - Успение Богородично, 14 септември - Кръстовден, 26 октомври - Св. Димитър (Димитровден), 6 декември - Св. Николай Чудотворец (Никулден), 25-27 декември - Рождество Христово. Освен тях официални държавни празнични дни са и няколко църковни празника с променливи или преходни дати - Възкресение Христово - три дни, Възнесение Господне и Празниците на сышествието на Св. Дух.

По тогавашните критерии това са т.нар. „господски“, „светителски“ или „вероизповедни“ празници, т.е. празниците от литургичния цикъл на църквата и празниците на най-популярните сред българския народ християнски светци. От всички тях единствено празникът на славянските апостоли Кирил и Методий още в епохата на Българското възраждане разчупва рамките на чисто църковно-богослужебната прослава и се превръща в първия истински национален празник. Втората група празници са династичните, т.е. датите, свързани с личността на монарха, в конкретния случай с княз Александър I. Това са датите на рождения му ден - 24 март, денят на избора му за български княз - 17 април, и тезоименият му ден - 30 август. Третата група са национално-политическите или държавно-народните, т.е. празниците, свързани с конкретни събития от българската история. Такъв е празникът на Освобождението - 19 февруари, записан в княжеския указ за празничните дни като „Заключавание на С. Стефанский мир“. Официален празник, разбира се, е и 1 януари - Нова година. 
Списъкът на Държавния съвет и княжеският указ от 1882 г. не предписват специални изисквания за отбелязването на официалните празници, освен известни ограничения в работното време на кръчмите и кафенетата, които трябва да бъдат затворени до 10 ч. предобед в празничния ден, и на магазините, които на определени празници трябва да бъдат затваряни за целия ден, а на други - само до 10 ч. Изключение се прави за фурните, аптеките, гостилниците и някои други подобни заведения. С указ № 1182 от 24 декември 1883 г. княз Александър I внася разграничение между народно-държавните и вероизповедните празници, като затяга ограничителния режим на публичните заведения. По силата на този указ народно-държавните празници са задължителни за всички граждани на страната, и публичните заведения, освен фурните, аптеките, касапниците и зарзаватчийниците, трябва да остават затворени през целия ден. За дните на вероизповедните празници ограничението се разпростира до времетраенето на църковната служба, т.е. до 11 ч. предобед².

$\mathrm{C}$ течение на времето празниците и от трите групи тьрпят развитие. Всяка обаче има своя специфична динамика на промяна. Образно казано, официалният календар се състои от три различни писти, по които празниците дефилират с различна скорост - едни кретат, други ходят, трети направо препускат. Най-бавна е вероизповедната писта, защото се основава на църковния календар, формиран и утвърден в течение на близо две хилядолетия. Въпреки това и тя се преобразява - някои църковни празници отпадат от официалния календар, други се явяват на тяхно място.

По-ярко изразена е динамиката по линията на династичните и политическите празници. Логично и закономерно е със смяната на монарха изцяло да се обновяват и свързаните с него празнични дни. Политическото развитие на България също маркира с най-съдбоносните си събития националния празничен цикъл.

За относително краткия седемгодишен период на управлението на княз Александър I (1879-1886) официалният държавен календар е маркиран с ярка русофилска окраска. Много от българските празници съвпадат едно към едно с руските, макар под друга формулировка. Всеизвестно е например, че един от най-популярните празници - 19 февруари, „Сключванието на С. Стефанский мир“ - всъщност косвено прославя възшествието на император Александър II Освободител (на крепостните селяни) на руския престол, респективно найважния по ранг руски държавен празник от времето на неговото царуване. Неслучайно на същата дата през 1861 г. е отменено крепостното право в Русия, а през 1878 г. е сключен Санстефанският мирен договор. По същия начин първият по ранг български държавен празник от този период - 17 април, „Възшествието на Княз Александър I на Българския престол“ - всъщност прославя и рождения ден на император Александър II, защото през 1879 г. Великото народно събрание в Търново съвсем съзнателно и целенасочено, тъкмо заради символичното съвпадение, избира тази дата, за да провъзгласи избора на първия български държавен глава. В официалния списък на празничните и неприсъствените дни датата 30 август, тезоименият ден на княз Александър I, е записана като двоен празник - и като тезоимен ден на руския император Александър II, а след смъртта му, на неговия приемник Александър III. От 1882 г. за няколко години като официален празник в България се чества и датата 1 март - „Денят на мъченическата смърт на Царя-Освободителя“ (загинал на 1 март 1881 г. в терористичен атентат). Затова не е чудно, че в началния период на развитието си официалният празничен календар на Княжество България съвсем естествено и закономерно носи родилните петна на празнично-обредната система на своята освободителка ${ }^{3}$.

Съединението на България и неговата военна защита през 1885 г. не само предопределят хода на българската история, но и цялостно променят облика на държавната и военната празнично-обредна система. Първопроходници на тази промяна са ръководителите и дейците на Съединението, самите те свидетели и участници в революционното движение, Априлското въстание и Руско-турската война, т.е. - живата връзка между две епохи в историята на България.

С инстинкта на истински народен трибун и самороден политически лидер Захари Стоянов успява да прозре огромния социално-политически потенциал на празника и да го превърне в мощно средство за мобилизиране на гражданското общество. За разлика от Княжество България, където официалната празнично-обредна система се оформя като руски дубликат, в Източна Румелия тази материя е оставена изцяло на вероизповедните общно- 
сти, всяка от които следва своя религиозен цикъл. Сред българското население на областта популярни са и празниците, свързани с Руско-турската война - не само 19 февруари, като датата на Санстефанския мирен договор, но и датите, на които са освободени отделните градове. Те ежегодно се отбелязват с молебени, панихиди и народни тържества. Също толкова обичан и популярен е и празникът на славянските апостоли св. св. Кирил и Методий, който през 1885 г. излиза на преден план като символ на въжделена политическа идея.

По чиста случайност или по мистична воля точно през пролетта на тази знаменита година се закрьгля емблематичен за българската културно-национална кауза юбилей - 1000 години от смъртта на св. Методий, 6 април. По инициатива на Българската екзархия и с подкрепата на двете български държави честването на това събитие се преврьща в грандиозна манифестация на българското национално единство. Празненствата в Пловдив и другите източнорумелийски градове се надпреварват по тържественост и масовост и се нареждат достойно до аналогичните прояви в Княжество България, в Македония и Одринска Тракия и навсякъде, където това е възможно по българското национално-историческо землище 4

Всички тези чествания и манифестации обаче са само прелюдия към събитията, които се разиграват в Пловдив в навечерието на 23 април 1885 г., чийто отзвук не само дълго отеква в областта, но предизвика и сериозно дипломатическо ехо сред представителите на Великите сили и балканските държави. На този ден по тогавашния Юлиански календар българите по традиция честват църковния празник на св. Георги Победоносец или Гергьовден. Той обаче е и официален държавен празник на Кралство Гьрция като тезоимен ден на крал Георгиос. Усетили новия дух на съединистката идея сред българите, пловдивските гърци и гъркомани, подбудени от гръцкото консулство, решават да им отговорят със същото оръжие, като превърнат Гергьовден в грьцка националистическа манифестация. В навечерието на празника местният в. „Филипопулис“ приканва своите читатели масово да честват празника и като по команда по домовете, магазините и кафенетата са провесени гръцки знамена. Българите в Пловдив обаче също отговарят. В резултат до вечерта всички гръцки знамена са изпокъсани и свалени, цялата украса унищожена, случват се няколко по-сериозни сбивания, проехтяват и два-три изстрела, за щастие без жертви. Пловдивският Гергьовден през 1885 г. остава български ${ }^{5}$.

Този момент е повратен и недвусмислено показва, че учреденият и председателстван от Захари Стоянов Български таен централен революционен комитет (БТЦРК) съзнателно и целенасочено е включил в организационната си стратегия използването на празниците, честванията и юбилеите като оръдие на съединистката идея. Дори само лаконичното хроникиране на събитията дава възможност да се усети градацията на гражданското и националното съзнание на българското население в Източна Румелия през пролетта и лятото на 1885 г.

На 20 април и в дните до края на месеца Източна Румелия става свидетел на незапомнени масови чествания на годишнината от Априлското въстание - Копривщица, Панагюрище, Перущица, Брацигово, Батак и цялата свещена топография на народната саможертва сякаш оживяват като предвестник на съдбоносни исторически събития 6 .

На 11 май традиционното честване на св. св. Кирил и Методий издига съединистката идея на още по-високо стъпало в гражданското съзнание на българите в автономната област. По инструкция на БТЦРК в честването на културно-просветния празник активно се включват членовете на опълченските дружества, които му придават подчертано политически характер. На места стават бурни антиправителствени демонстрации, произнасят се патриотични речи, тайно и явно се разпространява уставът на комитета. Така кирилометодиевската символика и празничност се превръща в трибуна за пропаганда на съединистката идея ${ }^{7}$.

На 19 май БТЦРК пак разиграва сценария от Гергьовден, но сега с ярка противоосманска окраска. На този ден турците в Източна Румелия, както и в цялата Османска империя, отбелязват празника Велядети-Хумаюн. В предходните години никой не му е обръщал публично внимание и дори няма запазени свидетелства как е протичал празникът и какво всъщност е представлявал - дали е бил рождения ден на султана, или деня на неговата интронизация. През 1885 г. обаче тази дата става знаменателна в предисторията на Съединението. Под предлог, че почивният ден е по-подходящ за всенародни празненства, дейците на БТЦРК преместват традиционното честване на гибелта на Христо Ботев от 21 на 19 май, който тогава се пада в неделя. Така отоманският празник се превръща в 
съединистка акция, в която главна роля пак играят опълченските дружества - един от найсилните, авторитетни и сплотени отряди на националнообединителното движение. Подобни манифестации с открита пропаганда на съединистката идея се провеждат и в други градове. Източнорумелйското правителство под натиска на Високата порта отговаря с масови арести на ръководители и участници и само попада в сценария на БТЦРК, който цели именно конфронтация между народа и управниците 8 .

По същия масово-революционен и противоправителствено-конфронтационен начин се организира и протича честването на годишнината от гибелта на Хаджи Димитьр и неговата чета на 18-21 юли. Заключителният събор на Бузлуджа събира хиляди поклонници от Източна Румелия и Княжество България, като един вид символично обединение на народа от двете страни на Балкана'. Годишнините на боевете при Стара Загора (20 юли) и Шипка (11 август) също внасят съществен дял в гражданската мобилизация на съединистката идея.

Колкото символично, толкова и практично последният голям празник, който е честван непосредствено преди акта на Съединението в нощта на 5 срещу 6 септември, е св. Александър Невски - 30 август. На пръв поглед безобидна в църковния календар, в оперативния план на съединистите тази дата концентрира в себе си ясни за съвременниците политически послания от официалната празнично-обредна система на Княжество България. По традиция освен това големите военни маневри на българската войска се свикват именно така, че религиозният празник на светеца воин и на неговите владетелстващи съименници да се чества сред войската. Така българските дружини, на някои от които впрочем патронен празник е именно св. Александър Невски, се оказват готови да посрещнат Съединението, а празничната му рамка е един вид авансова полица за благоразположението на Русия.

Така Захари Стоянов и дейците на БТЦРК допълват социално-политическата функция на празника с оригинален български принос. Съединистките лидери използват честванията на юбилеи, годишнини и празници, за да творят история, която от своя страна става част от Българския национален календар ${ }^{10}$.

Съединението и Сръбско-българската война през 1885 г., детронирането и абдикацията на княз Александър през 1886 г., изборьт и интронизацията на княз Фердинанд и окончателното скъсване на дипломатическите отношения между България и Русия през 1887 г. оставят траен отпечатък върху развитието на Българския национален календар.

Първата официална промяна е извършена веднага след интронизирането на княз Фердинанд. Новият български монарх се оказва по-разточителен по отношение на празниците в сравнение със своя предшественик. С указ № 78 от 31 декември 1887 г. той въвежда личните си празници в държавния календар на мястото на празниците на абдикиралия княз Александър I. Това са: 14 февруари - рожденият ден на княз Фердинанд, 18 май - тезоименият му ден, 2 август - възшествието му на българския престол. Освен това за официални празнични или „неприсъствени“ дни, като допълнение към вече съществуващите са обявени още пет църковни празника: 7 януари - Ивановден, 20 юли - Илинден, 8 септември - Рождество Богородично, 8 ноември - Архангеловден и 21 ноември - Въведение Богородично. Окончателно изчезва „Денят на мъченическата смърт на Царя-Освободителя“ (1 март), а 19 февруари вече не е „Заключавание на С. Стефанский договор“, а „Освобождението на България“"11. Освен смяната на наименованието, Празникът на Освобождението търпи и първата рязка промяна във формата и съдържанието си и вече се чества като „двоен“" празник, тъй като на 19 февруари 1886 г. е подписан Букурещкия мирен договор, с който официално завършва Сръбско-българската война.

Кризата в българо-руските отношения през 1887-1896 г. и непризнаването на княз Фердинанд като български монарх от Русия не преустановяват честването на празника, но се отразяват върху неговата тържественост. То се извършва в обичайния формат, но държавният глава рядко присъства лично на церемониите, а е заместван от някой представител на Двореца. Невинаги се провежда преглед и парад на частите от столичния гарнизон, макар че войската винаги е представена на църковната служба чрез свои генерали и офицери. За честванията през този период свидетелства отзив във в. „Народни права“ от 1889 г., орган на опозиционната тогава Либерална партия на д-р Васил Радославов: „19 Февруарий, на- 
родний празник на С. Стефанска България и сключвание Букурещский мир между България и Сърбия и тази година се отпразнува почти мълчаливо в столицата. По сведения, които имаме, и в провинцията, както и в столицата, този ден не се е славил особено“"12.

След подобряването на отношенията с Русия през 1896 г. честването на 19 февруари отново става по-ентусиазирано, а споменът за Букурещкия мирен договор постепенно заглъхва. Като своеобразен връх в този период може да се приеме отбелязването на 20-годишнината на Освобождението през 1898 г. Тогава, по свидетелството на българския печат, градовете в цялата страна били подобаващо „декорирани“ и навсякъде се извършили молебени при голямо стечение на народ, с военни паради и народни празненства. Хората се радвали и поздравявали като на Великден - най-популярния в България християнски празник Възкресение Христово ${ }^{13}$.

Отбелязването на тази крьгла годишнина обаче е по-скоро изключение, щом още на следващата година по повод честването на 19 февруари в. „Пряпорец“, орган на русофилската и опозиционна Демократическа партия, коментира: „Има повече от 10 години, от когато този празник, макар и да стои в календаря, се намира в един вид немилост пред българските управници“. Според вестника и политическото течение, което той изразява, Денят на Освобождението е „най-големият народен празник“, който трябва да се чества „като празник на нашето освобождение и като ден, който трябва да ни наумява за обединението на целокупна България“"14.

С указ № 23 от 11 април 1895 г. в официалния държавен календар е включен още един празник - 2 май, тезоименият ден на престолонаследника княз Борис ${ }^{15}$.

$* * *$

Българската официална празнична система навлиза в нов и по-високоорганизиран етап на границата на XIX и XX век. Тогава - през 1899-1900 г. - е изработен и приет първият Закон за празничните дни в Княжество България, който остава в сила до навечерието на Балканската война. Той обаче не внася съществени промени, а просто санкционира установената вече практика. Най-важната отлика е, че се появява нов държавно-народен празник - 6 септември, Съединението на Северна и Южна България. За да освободи място за новия празник, от официалния календар отпада 21 ноември, Въведение Богородично ${ }^{16}$.

Основното пространство на празника е църковният храм, а Българската православна църква чрез своите свещенослужители е главно действащо лице в честванията. Богослужението, молебенът или панихидата са задължителни елементи на всяко празненство, а в някои ритуали участва и войската. Честването на държавни празници изобщо тогава се характеризира със скромност и официалност.

Два празника обаче правят изключение и се отличават както със своята масовост, така и с оформянето на специфичен ритуал. Първият, по хронология и по значение, е 11 май - св. св. Кирил и Методий. В свободната българска държава Празникът на славянските апостоли Кирил и Методий е официален държавен празник и като такъв се чества още от първата година след Освобождението. Той неизменно присъства във всички княжески укази, които уреждат въпросите с празничните дни в България. За значението на кирилометодиевската символика свидетелства и фактьт, че най-високото по ранг българско държавно отличие в тази епоха е орденът „Св. св. Кирил и Методий“. Ежегодните училищни тържества и шествия на 11 май освен това осигуряват на празника постоянна масовост и неповторима жизнерадостност, които още повече го утвърждават като най-обичания български празник ${ }^{17}$.

Другият празник, който през първото десетилетие на XX век излиза от храма и увлича хората по улиците и площадите в България, е 19 февруари - Празникът на Освобождението. Историческото, политическото и идеологическото значение на това събитие го превръщат в своеобразен гравитационен център на цялата празнично-обредна система. Санстефанската символика пуска дълбоки корени в обществото и неговите сдружения, подхранвани от честванията на годишнините на Руско-турската война. Най-голямото, зрелищно и пищно дотогава честване е организирано през лятото на 1902 г., във връзка с четвъртвековния юбилей на боевете на връх Шипка и освещаването на храм-паметника „Рождество Христово“ в едноименното село. Неслучайно Върховният македоно-одрински комитет използва честването при подготовката и обявяването на Горноджумайското въстание през есента на с.г. ${ }^{18}$ 
Немалка роля за популяризирането на 19 февруари всъщност изиграва Върховният комитет, който избира датата на Освобождението за свой патронен празник. Именно той масовизира честването на Празника на Освобождението и внася нова обредност и символика в него. На тази дата македоно-одринските дружества в страната стават организатори на всенародни тържества, манифестации и увеселения, които навсякъде протичат с приблизително следната програма: след свършване на празничната служба в храма, на площада в населеното място се провежда митинг, на който председателят или друг оратор от дружеството държи патриотична реч; следва шествие из централните улици с дружественото знаме начело, с българския национален трибагреник и революционното червено знаме с траурните черни ленти, знамената на поборническо-опълченските дружества и другите патриотични организации и комитети, портретите на загиналите македоно-одрински революционери, много цветя, зеленина, музика. Върховният комитет превръща тържествата на този ден в общонационални и по значение и дух ги приближава до другия всенароден празник - 11 май, Св. св. Кирил и Методий. За първи път 19 февруари е отпразнуван масово и повсеместно като организационен празник през 1900 г. ${ }^{19}$

През 1903 г., когато се навършват 25 години от Освобождението на България, по разпореждане на Министерството на народното просвещение във всички училища в страната на 19 февруари се държат беседи за значението на тази дата за българския народ²0.

Тридесетата годишнина на Освобождението е чествана с голяма тьржественост през 1908 г. Тогава за пьрви път като едно от средоточията на празненствата се откроява Паметникът на Цар Освободител в София (построен точно срещу централния вход на Народното събрание и тьржествено открит на 30 август 1907 г.). За първи път учениците от столичните основни училища са изведени да дефилират с български и руски знамена заедно с опълченските, професионалните, юнашките, културните и други сдружения, македонските братства, гражданството. Многохилядното шествие се излива край паметника, като го отрупва с венци и цветя в знак на признателност, а после продължава по традиционния маршрут през Руското посолство към Паметника на Васил Левски. Все така масово и ентусиазирано празникът на Освобождението е честван и в страната ${ }^{21}$. За това, без съмнение, допринася предчувствието за съдбоносните политически събития, чиито знамения са лесно разпознаваеми дори за обикновените хора. Всъщност Празникът на Освобождението вече не е онова благоговейно преклонение пред Русия, което владее духовния и политическия живот на страната през 1878-1885 г., а най-популярният и мобилизиращ символ на българския национален идеал от онази епоха - освобождението и обединението на България в нейните естествени етнически и политически граници.

Тук е уместно да се отбележи, че единствената политическа сила в България, която убедено, последователно и демонстративно проявява неуважение към празника на Освобождението, е Българската работническа социалдемократическа партия, особено в „тесния“ ѝ формат. Тя игнорира повечето от датите в държавния календар заради техния династичен или религиозен характер, а специално в 19 февруари вижда възхвала на руския царизьм, уличаван от нея като жандарм на световния империализъм и потисник на руския пролетариат. Публикациите в нейния орган „Работнически вестник“ в броевете на или около празника са най-доброто свидетелство за това отношение. На другия полюс е Българската православна църква, която при всички обстоятелства и във всички епохи гледа на Празника на Освобождението като на символична връзка с православна и славянска Русия. Публикациите в синодалния официоз „Църковен вестник“" също са ярко доказателство за това.

С обявяването на независимостта на България на 22 септември 1908 г. в официалния държавен календар намира място още един важен, ако не и най-важният за тогава празник. Денят на Независимостта е честван още на първата си годишнина с рядко срещана дотогава пищност и разточителност. В Търново е организирано своеобразно повторение на церемониала с участието на главните герои, начело с царя, министрите и архиереите, с благодарствения молебен в „Св. св. 40 мъченици“, с прочитането на манифеста на Царевец и т.н. ${ }^{22}$ В София и във всички по-големи градове на страната също има благодарствени молебени, празнични илюминации, градински увеселения и други манифестации ${ }^{23}$.

Заедно с новия празник, в Българския национален календар се вселява и нещо ново и непознато дотогава - духът на разединение. За първи път един национален празник се 
превръща в повод за остра политическа конфронтация и разгорещени публични дебати. При това не става въпрос за тесните социалисти, които по силата на своите убеждения не признават и не уважават нито църковните, нито династичните празници. Открито и активно срещу честването на Деня на Независимостта, или както тогава добива публичност - „Царския празник“, се обявява една сериозна и солидна политическа сила, участвала в управлението преди и след това - Народната партия. Точно в дните на първото честване през 1909 г. из страната се провеждат околийски събрания на народняците за подготовката на предстоящия им партиен конгрес. Централният орган и местният печат на Народната партия изтькват редица доводи срещу честването, като се почне от формалния факт, че то не е предвидено в Закона за празничните дни, и се стигне до отричането на политическата целесъобразност на акта изобщо.

Срещу честването на Деня на Независимостта като официален държавен празник се обявяват и други обществени сили като издателите, редакторите и авторите на русофилския в. „Ден“ или републиканско-социалдемократическият кръг около в. „Камбана“ - и двата сравнително популярни и авторитетни за времето вестници. На същата позиция, но от съвсем други подбуди, застават и някои висши архиереи на Българската православна църква, като Варненско-Преславския митрополит Симеон например, който гледа на обявяването на независимостта като на държавен преврат.

Същата полемика се разгаря и през следващата година, когато отново е организирано общодържавно честване на Деня на Независимостта, без да бъде законодателно утвърден като официален празник. Полемиката дори още повече се изостря, защото през 1910 г. управляващата Демократическа партия организира честване и на 25-годишнината от Съединението на 6 септември (официален държавен празник от 1901 г.), при което част от ритуала се провежда при гроба на бившия министьр-председател Петко Каравелов. Последното е изтълкувано и разкритикувано от някои като „смесвание на едно народно празненство с името на П. Каравелова като политическо лице“, т.е. като опит за внасяне на елемент на партийност в национално събитие и официален празник ${ }^{24}$.

Така се ражда един стереотип - когато са на власт, партийните лидери и елити охотно участват в празнични церемониали и се къпят в светлината на публичността; когато са в опозиция, проявяват непримирима критичност и демонстрират спартанска въздържаност към всякакви форми на разточителност с държавни средства. Като своеобразен вербален код на тази закономерност в публичното пространство изплува понятието корупщия. И наистина, още със законодателно несанкционираните първи чествания на Деня на Независимостта, една от най-коментираните теми в опозиционния и независимия печат става корупцията на управляващите и борбата срещу нея. Заглавията на подобни статии сами говорят за своето съдържание - „Безразсъдна политика“, „Министьр покровител на крадците“, „Разтление по всички линии“, „Аферите във вътрешното министерство“ и пр. и пр. ${ }^{25}$

В началото на 1911 г. Народното събрание приема нов Закон за празничните дни, който не само включва Деня на Независимостта в официалния държавен календар, но прави и радикални промени в него. Отпадат няколко църковни празника (7 януари - Ивановден, 2 февруари - Сретение Господне, 6 август - Преображение Господне, 8 септември - Рождество Богородично, 14 септември - Кръстовден), както и повечето от династичните рожденият и тезоименият ден на царя и тезоименият ден на престолонаследника. Отпада дори празникът на Съединението, за да може през септември да изпъкне само и единствено Денят на Независимостта ${ }^{26}$.

Още на следващата година България навлиза в нов период от своето развитие, белязан от войните за национално обединение - Балканската, Междусъюзническата и Пьрвата световна война. Националнообединителната мисия отрежда на Българската армия съдбоносна роля. Заедно с нея на преден план в публичното пространство навлиза и военният празнично-обреден цикъл. По този начин един празник, който дотогава дори не фигурира в официалния държавен календар, неочаквано изпъква начело, изпълва се с ново съдържание и закратко се налага като най-значимата дата от Българския национален календар. Това е 15 ноември, Празникът на победите, учреден през 1898 г. като боен празник на Българската армия, възпоменаващ последния победен ден в Сръбско-българската война (превземането на Пирот на 15 ноември 1885 г.) $)^{27}$. 
По всяка вероятност, ако за България Балканската война беше завършила така триумфално, както започва, Българската армия щеше да чества празника си на друга дата, например 20 октомври, победата при Люлебургаз, 13 март, превземането на Одрин, а защо не и 4 ноември, евентуалния триумф при Чаталджа. Дори в Св. Синод на Българската православна църква вече се обсъжда идеята за определянето на ден, който да се чества като общонароден празник и в който да се поменават имената на всички загинали за националното обединение воини. В крайна сметка синодалните архиереи предвидливо решават да изчакат развитието на събитията до сключването на мира ${ }^{28}$. Тяхната предпазливост се оказва основателна. Вместо с триумф през 1913 г. войната завършва с национална катастрофа.

Намесата на България в Първата световна война връща Празника на победите към нов живот. Победоносното настъпление на българската армия срещу сръбските войски съвпада с позабравения боен празник. На 15 ноември 1915 г. противникът вече е разбит и се спасява с бягство, а почти цяла Македония е освободена. При това денят се пада неделя. Каква по-добра възможност за тържествено празнуване на победите! Така вероятно е мислил и главнокомандващият генерал Никола Жеков, който на 15 ноември в Главната квартира в Кюстендил подписва заповед № 85, с която поздравява целия личен състав на действащата армия и изрично подчертава, че „българският народ създаде от днешния ден един велик празник, който вещае на поколенията за неговите войнски добродетели и за неськрушимата му енергия“'29.

Празникът на победите се чества тържествено и в старите предели на страната. На молебена в съборния храм „Св. Неделя“ в София присъстват министри, генерали, офицери и други военнослужещи, много граждани. По-рано през деня в църквата на Военното училище се отслужва панихида в памет на загиналите и молебен за здравето на живите воини. След това юнкерите от първия специален клас на брой около 300 души полагат клетва. Тържеството е уважено от цар Фердинанд, министьр-председателя Васил Радославов и други високи гости. По-скромни тържества със същия формат - панихиди, молебени и речи - се провеждат и в други градове ${ }^{30}$.

През 1916 г. Българският национален календар търпи нова важна промяна. Заради преминаването от Юлианския към Грегорианския календар, т.е. от стария към новия календарен стил, всички празници правят преход от 13 дни и се установяват на нови дати. Така например 19 февруари става 3 март. Точно в тези години обаче празникът на Освобождението не е честван официално, тъй като България и Русия се оказват от двете страни на фронтовата линия. През 1916 г. храмът „Св. Александър Невски“ в София, построен именно като паметник - символ на Освобождението, е преименуван с постановление на Министерския съвет на „Св. св. Кирил и Методий“. Това е направено, въпреки несъгласието на Св. Синод на Българската православна църква (и по нейно настояване е отменено през 1919 г.) $)^{31}$.

Случайно или не, точно на 3 март 1918 г. е подписан и Брест-Литовският мирен договор. Той обаче никога не е честван във връзка с празника на Освобождението нито тогава, нито по-късно.

За сметка на това честването на Празника на победите процъфтява. Заради календарната промяна той вече се отбелязва на 27 ноември. Освен това в неговото навечерие българската войска постига нови победи в Македония и Добруджа. Без излишна пищност, но иначе достатьчно тържествено през 1916 г. Празникът на победите е отбелязан както на фронта, така и в тила. В Кюстендил при Главната квартира има панихида, молебен и парад, приет лично от главнокомандващия генерал Жеков. Където е възможно, същото се прави и по частите. В София панихидата и молебенът са пак в „Св. Неделя“ с вече обичайната публика. Така е на следващата година. Пробивът на Македонския фронт при Добро поле на 17 септември 1918 г. и капитулацията на България обаче правят неуместно всяко празненство.

Най-значителният и съдбоносен поврат в историята на Празника на победите настъпва през 1919 г. Победителите, които тогава диктуват мира, показват малко съобразяване с правата на победените и никакво зачитане на тяхното достойнство. За това, че дръзва да осъществи националното си обединение - естествено и законно право на всяка страна България е наказана жестоко от Великите сили и техните малки съюзници. Ньойският 
договор е можел да бъде подписан още с пристигането на новия министьр-председател на България в Париж на 19 ноември. Вместо да пристъпят към полагане на подписите върху готовия документ, представителите на Антантата сякаш потъват вдън земя. Стамболийски е настанен в хотел „Пале дьо Мадрид“ в покрайнините на Булонския лес, където българската делегация пребивава от началото на Парижката мирна конференция в условията на фактически арест. На същия изолационен режим е подложен и българският министърпредседател. Това забавяне в най-голяма степен се дължи на сръбската делегация, която желае с едно преднамерено и търсено погазване на българското национално достойнство изобщо и на българската бойна чест в частност, да се реваншира за претьрпените поражения и в Сръбско-българската, и в Първата световна война. На 27 ноември, точно в деня, когато България е чествала Празника на победите, Ньойският договор е подписан с процедура, която отнема 25 минути ${ }^{32}$.

В периода между двете световни войни Българският национален календар търпи нови промени. Най-важните от тях са продиктувани от смяната на монарха. На 3 октомври 1918 г. цар Фердинанд абдикира в полза на престолонаследника княз Борис. Така тази дата автоматично се превръща в официален държавен празник - „Възшествието на Цар Борис III на Българския престол“. В календарното пространство новият празник се оказва в съседство с две други съдбоносни събития от българската нова и най-нова история - обявяването на независимостта на 22 септември и началото на Балканската война на 5 октомври. Впрочем с въвеждането на новия календарен стил през 1916 г. Денят на Независимостта вече се измества на 5 октомври. Става така, че на две съвсем близки дати - 3 и 5 октомври - се събират три важни чествания - интронизацията на новия цар, държавната независимост и войната за национално обединение. Българската войска, на която царят е върховен главнокомандващ, особено държи на тази връзка и в деня на празника военните издания не пропускат да я изтъкнат. Така празникът на монархическия институт, държавния суверенитет и националното обединение символично се сливат в личността на цар Борис III. Разбира се, никой не си дава труда да поясни, че датата 5 октомври всъщност е по стария календарен стил, иначе Балканската война би трябвало да се отбелязва на 18 с.м. Тогава обаче и символиката нямаше да бъде толкова концентрирана, ясна и въздействаща ${ }^{33}$.

Сериозни трансформации търпят и други ключови празници от Българския национален календар. Един от тях дори изчезва завинаги. Това е Празникът на победите, чиято дата - 27 ноември - все повече започва да се свързва с протестните демонстрации срещу Ньойския договор. Последното му честване е през 1925 г. Оттогава като боен празник на българската армия се установява 6 май, Гергьовден. На тази дата през 1926 г. в. „Народна отбрана“" излиза със специален празничен брой, в по-голям формат от обикновено и отпечатан с червен шрифт, целият изпълнен със статии за Деня на храбростта и на победите, бойния празник на българската войска ${ }^{34}$.

Празникът на Освобождението на 3 март продължава да се чества официално, макар и скромно. Най-скромно го честват земеделците през 1919-1923 г., както впрочем се отнасят и с другите празници от националния календар. Освен че по този начин искат да изразят пренебрежително отношение към монархическия институт, те хранят предубеждение срещу празника на Освобождението и заради присъствието на бялата емиграция в страната, от която се страхуват като потенциален политически и военен противник. С цел да принизят значението на празника като символ на националнообединителната идея, земеделците преместват честването от 3 на 4 март, когато по народния календар се чества Тодоровден. Така традиционната празничност на София на този ден през 1922 г. се „обогатява“ с конни състезания, организирани от Дружеството на столичните файтонджии. За сметка на това градът е украсен само с четири национални знамена, а честването минава по-вяло от обикновено ${ }^{35}$.

Българската комунистическа партия наследява и доразвива тесняческата омраза към празника на Освобождението, за което в частност свидетелства адската машина, взривена в театър „Одеон“ навръх 3 март 1922 г. Точно за празничния ден там била насрочена сказка на руски журналист-емигрант за стара и нова Русия. Сред жертвите на терористичния акт едва не попада и проф. Иван Шишманов, който имал резервирано място на пьрвия ред, но лека настинка го задържа у дома и му спасява живота ${ }^{36}$. Косвено срещу празника на 
Освобождението и неговата символика е насочен и атентатът в „Св. Неделя“ на Разпети петьк 1925 г., тъй като дотогава храмът е средоточие на всички официални чествания за 19 февруари / 3 март.

Правителството на Демократическия сговор реабилитира празника на Освобождението и го връща на оригиналната му дата, 3 март. Още през 1924 г. той е честван много по-тьржествено от преди с панихида и молебен в храма „Св. Неделя“, на която присъстват цар Борис III, министри и военни, а след това многолюдното шествие прави обичайното поклонение до Паметника на Цар Освободител, предвождано от опълченците със Самарското знаме. С панихиди, молебени и граждански тьржества празникът е честван и в цялата страна ${ }^{37}$. След 1925 г. църковните ритуали се пренасят в храм-паметника „Св. Александър Невски“, осветен предходната година, понякога придружени с преглед и парад на войската, но винаги с поднасяне на венци и цветя пред Паметника на Цар Освободител. Празненствата завършват с тържествено събрание, обикновено в салона на „Славянска беседа“. Най-тържествено и масово са празнувани крьглите годишнини - 50-ата през 1928 г. и 60-ата през 1938 г. По този повод има молебен и панихида в „Св. Александър Невски“, преглед и парад на частите от столичния гарнизон, шествие до Паметника на Цар Освободител, тьржествено събрание. През 1934 г. е осветен още един паметник, който веднага се преврьща в средоточие на държавна и народна признателност - Паметникът на свободата на връх Шипка.

Празникът на Освобождението се отбелязва като официален държавен празник дори в годините на Втората световна война. От 1941 г. той се чества и в Македония като празник от Българския национален календар ${ }^{38}$.

В годините между двете световни войни всички официални и неофициални празници носят ярка национална символика и се стремят да изтъкнат приемствеността между възрожденските ценности и националните идеали като дълг и повеля за личността, държавата и обществото. Наред с традиционните православни празници и най-популярните дати от държавния календар, като 3 март - Освобождението на България, 24 май - Деня на славянските апостоли Кирил и Методий, и 3-5 октомври - Независимостта, Възшествието и Балканската война, тогава завоюват публичност и някои нови неофициални чествания, като Деня на книгата, Деня на детето, Деня на майката, Деня на Паисий Хилендарски и др. По инициатива на българския интелектуален елит в националния календар се появява нов празник, който заедно с 24 май, Деня на славянските апостоли и на българската просвета и култура, ще отмерва пулса на духовния живот - 1 ноември, Денят на народните будители. Той е въведен в официалния календар със специален Закон за допълнение на закона за празниците и неделната почивка, приет от Народното събрание на 13 декември 1922 г. Законът съдържа само един член, който постановява учредяването на новия празник, чието официално наименование е „Празнуване паметта на заслужилите българи ${ }^{\text {‘39. }}$.

На коренно противоположна идеологическа основа се изгражда официалният празничен календар след 9 септември 1944 г. Българската комунистическа партия използва всички ресурси на тоталитарната държава, за да изтрие от съзнанието на българина и наймалката следа от официалната празнична символика на предишната епоха.

През 1945 г. е организирано първото всенародно честване на Септемврийското въстание. Тогава във в. „Работническо дело“ с авторитета и текстовете на Георги Димитров, Васил Коларов и Вълко Червенков е канонизирана тезата за „двата септември“ - 23 септември 1923 и 9 септември 1944 г. „Между двата септември - в 1923 и в 1944 г. - съществува пряка връзка: единият септември води към другия. Единият започна борбата за събаряне на фашизма, другият победоносно я завърши“, - кратко и ясно обяснява В. Червенков ${ }^{40}$. Датата 9 септември пък вече символизира всичко онова, което формира смисъла и съдържанието на национален празник - „свободна, независима, демократическа и мощна България с осигурена национална независимост и държавен суверенитет“ (В. Коларов $)^{41}$.

На 16 септември 1946 г. монархията окончателно е ликвидирана и България е провъзгласена за Народна Република. Официално е ликвидирана и старата празнично-обредна система. Най-важният празник в Българския национален календар става 9 септември под името „Ден на свободата“ - той е средоточието на идеологическата и политическата гравитация, около която ще се въртят всички други официални и неофициални празници. Съперничи му само 7 ноември, „Великата октомврийска социалистическа революция“, 
когато се провеждат и военни паради. Религиозните празници са натикани между стените на храма под обсадата на „научния атеизъм“. За да не остане и помен от старите „националистически“ и „монархически“ дати и събития, като Съединението, Независимостта или Балканската война, освен с официалните празници, годишният календар е упльтнен и с редица „бележити“ дати, които да обслужват пропагандата на комунистическия режим. Така тоталитарната държава се сдобива с тотално идеологизиран празничен календар.

Ето как например изглеждат месеците септември и октомври според празничния календар на в. „Отечествен фронт“ от 1950 г.: 9 септември - Народното антифашистко въстание в България, Ден на свободата, 16 септември - Обявяването на България за Република, 21 септември - началото на Лайпцигския процес, 23 септември - Септемврийското въоръжено антифашистко въстание, 27 септември - Ден на Земята, 1 октомври - излизането на Краткия курс по история на ВКП (б), 5 октомври - първата декларация на Информбюро, 7 октомври - създаването на ГДР, 20 октомври - освобождаването на Белград от съветската армия, 28 октомври - създаването на Чехословашката република ${ }^{42}$.

А ето как изглеждат историческата традиция и празничният цикъл за м. септември според „Червения народен календар“ на в. „Работническо дело“ от 1988 г.: 1 септември - Международен ден на мира и на профсъюзните действия за мир, 2 септември - Национален празник на Социалистическа република Виетнам, 8 септември - Международен ден на солидарността на журналистите, 9 септември - Ден на свободата, национален празник на Народна Република България и национален празник на Корейската народно-демократична република, 11 септември - Международен ден в памет на жертвите на фашизма, 15 септември - Празник на органите на МВР, 20 септември - Международен ден на мира, 23 септември - Ден на Българската народна армия и празник на Държавната пионерска организация „Септемврийче“, 27 септември - Международен ден на туризма ${ }^{43}$.

На заден план минават дори 3 март и 24 май. И двете дати са изхвърлени от „националния““ календар (по-късно 24 май е реабилитиран), но поне им е оставено правото да бъдат чествани по някакъв начин.

Интересна е съдбата на празника на Освобождението. От 1945 г. до края на 50-те години датата 3 март се отбелязва главно със скромни събрания, които бледнеят пред парадното честване на 23 февруари, Деня на Съветската армия, официално провъзгласена за „освободителка“ на България от „монархо-фашистко иго“. За 23 февруари в. „Работническо дело“ неизменно излиза с уводни статии и съдържание, концентрирано около лозунга „Съветската армия - армия освободителка“. В София на този ден се провежда тържествено събрание с участието на членовете на Политбюро на ЦК на БКП и членовете на Министерския съвет, подобни събрания се провежда и в провинцията, от окръжните центрове до фабричните колективи. В докладите и публикациите обикновено се развива темата за Съветската армия като „двойна освободителка““ - първия път през 1878 г., втория път през 1944 г. На „Второто освобождение“ обаче се посвещава близо 80\% от обема на текстовете ${ }^{44}$. Интересното е, че така се прави и когато се чества Трети март - основната част от текстовете пак е за „Второто освобождение“. Всъщност през тези години Празникът на Освобождението от османско иго се отразява в печата по-скромно дори в сравнение с празника на партийния печат, 1 март, и Международния ден на жената, 8 март. За 9 и 23 септември и 7 ноември пък изобщо не може да става и дума за сравнение.

През тези години партийният официоз съобщава за скромни чествания на Трети март с поднасяне на цветя и венци при Паметника на Освободителите, както официално е преименуван Паметникът на Цар Освободител. Променен е и текстът на паметника, който сега адресира народната признателност не до Царя Освободителя, а до руския народ. Все пак цяло чудо е, че паметникът изобщо оцелява, при условие, че редица други паметници за Руско-турската война в страната по същото време са унищожени. Може би само неочакваната смърт на Сталин през 1953 г. го е спасила от подобна участ ${ }^{45}$.

Действително, след смъртта на Сталин, както изобщо по отношение на целия живот в България, така и в частност за празника на Освобождението се забелязва известно размразяване и съживяване. Статиите за Трети март вече не се крият на задните страници, а излизат напред като уводни, формите на публичната признателност стават по-официални, тържествени и масови. Може да се приеме, че окончателният прелом настьпва през 1958 г., когато се отбелязва 80-годишнината на Руско-турската война. Още на 28 февруари 
в БАН се провежда научна сесия за Освобождението, тържествени събрания, изложби и други мероприятия има и в много градове на страната. В навечерието на празника в столицата се открива изложба с произведения на руски и румънски художници, а на самия ден има тържествено събрание в Народния театър и поклонение пред паметниците за войната с поднасяне на венци и цветя ${ }^{46}$. Партийният официоз излиза с уводна статия, която от името на целия български народ отдава почит на „падналите за свободата на България 200000 синове на руския народ““47. Впоследствие това число на руските жертви, както и крилатата фраза на Георги Димитров: „За българския народ дружбата със Съветския съюз е тъй жизнено необходима, както сльнцето и въздуха за всяко живо същество“, се преврьщат в неизменни спътници на тържествените чествания за Трети март.

Въпреки че на Деня на Освобождението започва да се обръща по-голямо внимание в светлината на формулата за „двойните освободители“, датата остава извън официалния празничен календар. Изключение е направено само за 100-годишнината на Освобождението през 1978 г., когато 3 март извънредно е обявен за неработен ден. През тези години обаче празникът на Освобождението е изчистен из основи от автентичното си съдържание като символ на националното освобождение и обединение и се инструментализира политически и идеологически единствено като символ на „вечната“ и „нерушима“ дружба между България и СССР.

Началото на края на комунистическия режим след 10 ноември 1989 г. открива нов период в развитието на празнично-обредната система на българската държава. Още на следващата година 3 март е обявен за национален празник под името „Ден на Освобождението на България от османско иго“. Това става с указ на Държавния съвет на НРБ № 236 от 27 февруари с.г., подписан от неговия председател Петър Младенов ${ }^{48}$. Парадоксалното от историческа гледна точка е, че инициативата и изпьлнението принадлежат на БКП, която винаги е игнорирала националната същност на празника и го е подменяла с интернационална, а ѝ опонира Съюзът на демократичните сили $(\mathrm{CДC})$, който се ражда с претенцията, че отстоява национална политическа традиция. Оттогава до днес целият преход, вече повече от 25 години, минава в полемика „за“ и „против“ Деня на Освобождението на България от османско иго като национален празник. Старите течения на в. „Дума“ (до 31 март 1990 г. в. „Работническо дело“) и в. „Демокрация“ свидетелстват за онова яростно манихейско раздвоение в националното съзнание, доведено до ирационално, почти мистично разбиране на празника на Освобождението като източник на всяко добро или всяко зло в политическия живот на България, като панацея за нашите недъзи или заплаха за нашите добродетели, като алфа и омега на политическите ни страсти.

Организацията и изпълнението на първото честване на Деня на Освобождението като национален празник изцяло е монополизирано от БКП, защото тя като управляваща партия владее институциите, а СДС все още владее само улиците. Благодарственият молебен в храма „Св. Александър Невски“, чийто праг за първи път е прекрачен вкупом от най-емблематични лица на доскоро войнстващо атеистичния комунистически елит, дава повод на опозицията да обвини управляващите в лицемерие. След молебена има поклонение пред Паметника на Цар Освободител (все още с фалшифицирано име и надпис), а вечерта тържествено събрание в Народния театър. С църковни служби, поклонения и тържествени събрания празникът се чества и в Плевен, Стара Загора, Шипка и други места ${ }^{49}$.

През 1991 г. обаче честването на Трети март се превръща в поле на остра конфронтация между БСП и СДС, въпреки че държавният глава, а следователно и институцията, която представлява, отразява политическите идеи и воля на демократичната опозиция. Официалния протокол за деня е ритуал пред Паметника на Незнайния войн с участието на президента Желю Желев предобед, панихида и молебен в храм-паметника „Св. Александър Невски““ след това и тържествена заря-проверка пред Народното събрание вечерта. В навечерието на празника обаче представителите на демократичната опозиция в Крьглата маса се срещат с председателя на Дьржавния съвет Петър Младенов, за да обсъдят въпросите за националния празничен календар. СДС настоява за промяна на националния празник и за обявяване на Великден и Коледа за официални празнични дни, БСП категорично се противопоставя на това предложение. Президентът Желев заема помирителна позиция: „Всички национални празници, както и начините за провеждането им, трябва да бъдат 
решени чрез референдум. Що се отнася до Трети март, това е светъл празник за нас. Той трябва да бъде ден на национално единство, а не трибуна за изява на политически амбиции, които да се поставят над народните интереси“б50. Празникът на Освобождението обаче се превръща точно в онова, което според държавния глава не бива да бъде.

В следващите няколко години Трети март продължава да бъде заложник в острата политическа схватка между двете основни политически сили. За съжаление, те страдат от обща болест - искат бързо да забравят тоталитаризма, но не помнят нищо или само твърде малко от епохата на националната държава. СДС остава непримирим противник на празника на Освобождението като символ на съветското влияние и не вижда нищо национално в него. За привържениците на БСП той не е случаен исторически продукт или благодетелен подарък, а произтича от хода и логиката на Българското национално възраждане.

В ранните години на прехода публицистичните дебати в медиите задължително резонират по улиците, понякога и в по-остри форми. Привържениците на СДС в деня на националния празник се събират на политически митинги, привържениците на БСП предпочитат да присъстват на официалните церемонии. Празничните прояви на „сините“ са съпьтствани с актуални политически лозунги на деня. Нерядко се стига и до пререкания, освирквания и други форми на взаимно неуважение дори по време на тържествените ритуали. Подобни инциденти стават не само в столицата, но и в страната, като еднакво подхранват със скандални факти публицистиката ${ }^{51}$. Така Трети март се оказва окован с обрьчи на разделение, непримиримост и омраза, които още по-здраво се „набиват“ от обединените усилия на медийно-площадния тандем.

$$
* * *
$$

След 1997 г., когато представителят на СДС Петьр Стоянов е избран за президент, конфронтацията по случай Трети март рязко се смирява. Тогава за първи път от началото на прехода той действително се преврьща в ден на национално съгласие. Новият редакционен и авторски екип на в. „Демокрация“ се отнася с по-голямо уважение към празника, опитва се да го инкорпорира в европейската перспектива на България, отново лансира идеята за „Ново българско възраждане“ “52. Явяват се и нови обредни форми, като факелното шествие от Паметника на Незнайния воин до Националния дворец на културата, организирано от Националното сдружение „Мати Болгария““, Общобългарския комитет „Васил Левски“ и Общонародната фондация „Христо Ботйов“"53.

През пролетта на същата година Обединените демократични сили (ОДС) печелят парламентарните избори и след президентския пост овладяват и държавното управление. Така на 3 март 1998 г. на тях се пада да честват 120-годишнината от Освобождението, а техните лидери да се наредят до руския посланик - нещо, което само допреди няколко години скандализира „сините“ симпатизанти. С подобаваща официалност празникът на Освобождението се отбелязва през целия мандат на президента Петър Стоянов (1997-2001), а най-важните средоточия на тържествените ритуали са в София (поклонение пред Паметника на Незнайния войн, панихида и молебен в храм-паметника „Св. Александър Невски“ и тържествена заря-проверка пред Народното събрание и Паметника на Цар Освободител и на Паметника на свободата на врьх Шипка ${ }^{54}$.

В периода 1998-2001 г. обаче официалната държавна обредност се концентрира около друг празник, който макар да не е със статута на „национален“, излиза на преден план и за известно време засенчва останалите. Това е Денят на независимостта - 22 септември, върнат в официалния празничен календар с решение на Народното събрание от 10 септември 1998 г. ${ }^{55}$ Странно защо обаче датата за честването на Деня на Независимостта е определена по стария календарен стил, отменен още през 1916 г., т.е. на 22 септември, а не по актуалния, според който би трябвало да бъде на 5 октомври, както е честван в периода между двете световни войни. Единственото логично обяснение, ако се игнорира хипотезата за некомпетентност, е, че това е направено преднамерено, с цел новият стар празник да се вклини между „двата септември“ и по този начин да ги изтласка от публичното пространство и общественото съзнание.

През 1998 г. е възстановен още един празник от националния календар - Денят на Съединението на България, 6 септември. Също като Деня на Независимостта, и той е възстановен на датата по Юлианския календар, а не по актуалния календарен стил. 
Първото официално честване на Деня на Независимостта се провежда във време на изострена вътрешнополитическа конфронтация, която налага своя отпечатьк върху празненствата. Центърьт на тържествата за 22 септември е във Велико Търново, където присъства политическият и държавният елит на управляващата коалиция Обединени демократични сили (ОДС). Подобаващи манифестации се провеждат и в други градове на страната. Българската социалистическа партия (БСП) бойкотира Деня на Независимостта и от своя страна освен традиционното за нея честване на 9 септември организира - като един вид контрачестване на официалния празник - национално възпоменание на 75-годишнината от Септемврийското въстание.

Конкуренцията между Деня на Освобождението и Деня на Независимостта, както и носталгията към „двата септември“, пак възбуждат стихналата за известно време дискусия по въпроса на коя историческа дата приляга да се отдава всенародна почит като национален празник. С този въпрос България навлиза и в новото хилядолетие. Задават го мнозина, сред които и журналистът Петко Бочаров, който в статия във в. „Демокрация“ през 2000 г. със заглавие „Националният ни празник е сбъркан“, категорично се обявява против Трети март, като се позовава и на мнението на неназовани „сериозни политици и историци“, убедени в същото: „Но защо и Народното събрание, и президент издигат като национален празник на българите дата, която в хилядолетната ни история е повече позорна, отколкото славна, и загърбват деня, в който страната ни със собствени усилия успява да си извоюва правото на международноправен субект“, - пита популярният журналист дълголетник и призовава парламентарното мнозинство на ОДС „да поправи допуснатата грешка“"56. Бурни страсти предизвикват и честванията на „двата септември“ - 9 септември, „Социалистическата революция“, и 23 септември, „Септемврийското антифашистко въстание“, - които симпатизантите на БСП продължават да отбелязват.

$$
* * *
$$

Честването на празниците от националния календар навлиза в нов етап през двата президентски мандата на Георги Първанов (2002-2012 г.). Тогава на политическата сцена изгрява нова политическа сила - Националното движение Симеон Втори (НДСВ), която разбива двуполюсния модел на „червено“ и „синьо“, респективно на ляво и дясно. В такава политическа обстановка президентьт Г. Първанов лансира през 2003 г. идеята за „нов прочит на историята“, която да помири нацията: „Крайно време е да разберем, че имаме шанс като нация, само ако успеем да прочетем поновому историята, ако наистина успеем да направим необходимото, за да постигнем помирение. Това не е отказ от забрава! Помирението означава да разберем, че има място в българския Пантеон за всички“б5.

В духа на концепцията за помирението и новия прочит на историята отбелязването на бившите празници от епохата на тоталитарния режим, стриктно тачени дотогава от БСП, остава на личната съвест и частната инициатива на партийните симпатизанти (т.е. тихомълком се преустановява), а честването на официалните празници се изпълва с нарастваща тържественост и нови ритуали. За Празника на Освобождението това се почувства още при първото му отбелязване с участието на президента Първанов през 2002 г. Тогава при прегледа на гвардейската рота и посрещането на Самарското знаме пред Паметника на Незнайния войн за първи път прогърмяват 20 топовни салюта. За първи пьт, при това от освещаването през 1934 г., както твърди в. „Дума“, 985-те стъпала на Паметника на свободата на Шипка са изкачени от титулярите на трите най-важни държавни институции - президентът Георги Първанов, министър-председателят Симеон Сакскобургготски и председателят на Народното събрание Огнян Герджиков ${ }^{58}$.

Честването на Трети март отбелязва своя апогей в епохата на прехода през 2003 г., когато по случай 125-годишнината от Освобождението на България в страната пристига официална руска делегация, водена от президента на Руската федерация Владимир Путин. По имперски пищните тържества и ритуали подробно са хроникирани от вестниците, а най-подробно от в. „Дума“, който от 2001 г. вече не се води орган на БСП, а „национален всекидневник“. Това ме освобождава от необходимостта да ги преразказвам и тук. Затова пък ще отбележа само два любопитни факта. Първият - че според специално направено за целта социологическо проучване $57 \%$ от българите се определили като русофили, $20 \%$ като русофоби и $22 \%$ - заели неутрална позиция ${ }^{59}$. Вторият - че навръх 3 март, когато Първанов и Путин поднасят венци пред Паметника на свободата на Шипка, на летище 
„Сарафово“ край Бургас кацат първите два американски самолета-цистерни с назначение да оказват логистична подкрепа в предстоящата война срещу Ирак ${ }^{60}$.

В следващите години от мандата на президента Георги Пьрванов не само националният празник, Денят на Освобождението на България от османско иго, но и другите държавни празници - особено 6 май, Денят на храбростта и Българската армия (или Гергьовден по народния календар, имен ден на държавния глава), 6 септември, Денят на Съединението на България, и 22 септември, Денят на Независимостта - се честват с голяма официалност, както никога преди това не са успявали или не са възнамерявали предходниците му от прехода. Това особено ярко проличава при честванията на 100-годишнината на Независимостта през 2008 г., които по своята тържественост и размах могат да се сравняват само с първите чествания от времето на цар Фердинанд. Но също както тогава, или както при възстановяването на празника през 1998 г. от правителството на ОДС, опозицията използва събитието, за да открие активния политически сезон. И сякаш по традиция основният лозунг пак е същият - корупцията на управляващите и борбата срещу нея.

$* * *$

Може да се каже, че по отношение на Българския национален календар преходът вече е завършил, с едно изключение. Официалните празници, които се честват днес, в голяма степен отговарят на историческата традиция от епохата преди Втората световна война и се радват на обществен консенсус. Това са: 1 януари - Нова година, 3 март - Ден на Освобождението на България от османско иго - национален празник, 1 май - Ден на труда и на международната работническа солидарност, 24 май - Ден на българската просвета и култура и на славянската писменост, 6 септември - Ден на Съединението, 22 септември - Ден на Независимостта на България, 1 ноември - Ден на народните будители - неприсъствен за всички учебни заведения, 24 декември - Бъдни вечер, 25 и 26 декември - Рождество Христово (Коледа), Великден (Разпети петък, Страстна събота и Рождество Христово) - според църковния календар на подвижните им дати през пролетта. Изключението е тъкмо националният празник - Трети март.

На 22 януари 2012 г. с избора на нов държавен глава - президента Росен Плевнелиев - се откри и нов период в честването на националния празник на Република България. Още в първото си слово по този повод, след тържествената заря-проверка пред Народното събрание в София държавният глава не спомена Русия в контекста на историческата си ретроспектива. В навечерието на празника през 2013 г., точно когато скулптурната композиция от Паметника на Цар Освободител беше временно вдигната за реставрация, депутат от Синята коалиция (поредното превъплъщение на изворното СДС) внесе предложение в Народното събрание за неговото окончателно демонтиране и заместване с паметник на хан Крум. Изобщо през мандата на президента Плевнелиев стихналата дотогава дискусия „за“ и „против“ Трети март, Деня на Освобождението, се разгоря с нова сила. Допълнителна енергия и страст очевидно вля и хибридната война, която стана актуална в България след анексията на Крим и събитията в Източна Украйна.

Мнението на политическите елити обаче сякаш не се споделя от обикновените хора. За това свидетелстват хилядите софиянци, които на 3 март 2016 г. се преклониха пред реликвите на Освобождението в Националния исторически музей и Националния военноисторически музей в столицата, над стоте хиляди българи от цялата страна, които се изкачиха на Шипка, и многолюдните спонтанни прояви из цялата страна. Съмнение няма - това е знамение, че националният празник и занапред ще продължава да привлича чувствата на хората, независимо дали ще бъдат чувства на признателност или отричане, на симпатия или антипатия, на любов или омраза. Очевидно българският народ още търси своята истинска душа...

1 Дьржавен вестник. - 1882. - № 130. - 13 ноември.

${ }^{2}$ Пак там. - 1884. - № 17. - 18 февр.

${ }^{3}$ Елдъров С. Денят на Независимостта в Българския национален календар // Независимостта на България, 1908 - София, 2010. - С. 443-446.

${ }^{4}$ Кирил, Патриарх Български. Българската екзархия в Одринско и Македония след Освободителната война (1877-1878). - Т. 1 (1878-1885). - Кн. 2. - София, 1970. - С. 90-108.

${ }^{5}$ Марица. - 1885. - № 709. - 26 апр.; Съединението 1885. Спомени. - София, 1985. - С. 230.

${ }^{6}$ Марица. - 1885. - № 710. - 30 апр. 
${ }^{7}$ Съединението 1885. Спомени. - София, 1985. - С. 51.

${ }^{8}$ Часът на Съединението удари. Българският печат и Съединението. - София, 1985. - С. 218-221.

${ }^{9}$ Марица. - 1985. - № 734. - 26 юли.

${ }^{10}$ Елдъров С. Празникът като единство: Непознатата история на Българското съединение от 1885 г. // Обществото на знанието и хуманизма. - Т. 8. - София, 2010. - С. 321-328.

${ }^{11}$ Държавен вестник. - 1888. - № 4. - 12 ян.

${ }^{12}$ Народни права. - 1889. - № 107. - 22 февр.

${ }^{13}$ Мир. - 1898. - № 500. -21 февр.

${ }^{14}$ Пряпорец. - 1899. - № 66. -21 февр.

${ }^{15}$ Дьржавен вестник. - 1895. - № 82. -18 апр.

16 Закон за празничните дни в Княжеството. - София, 1900.

${ }_{17}$ Симеонова Г. Проблеми на Кирило-Методиевата празничност. - Т. 1. - София, 1993; Т. 2. София, 2007.

${ }^{18}$ Силянов Х. Освободителните борби на Македония. - Т. 1. - София, 1983. - С. 163.

${ }^{19}$ Елдъров С. Борбите за национално освобождение, обединение и независимост в огледалото на Българския национален календар // Дупница и Дупнишко в борбите за национално освобождение, обединение и независимост. - Дупница, 2009. - С. 21-35.

${ }^{20}$ България. - 1903. - № $600-18$ февр.

${ }^{21}$ Дневник. - 1908. - № 2003. - 18 февр.; № 2004. - 19 февр.

22 Ден. - 1909. - № 1970. - 22 септ.

${ }^{23}$ Пак там. - 1909. - № 1971. -23 септ.; № 1972. -24 септ.

${ }^{24}$ Пак там. - 1910. - № 2309. - 7 септ.

${ }^{25}$ Елдъров С. Денят на Независимостта... - С. 443-446.

${ }^{26}$ Закон за празниците и неделната почивка. - София, 1911.

${ }^{27}$ Елдъров С. Празникът на победите - 27 ноември. Непознатата история на бойния празник на Българската армия // Военноисторически сборник. - 2004. - № 4. - С. 3-7.

${ }^{28}$ Централен държавен архив (ЦДА), ф. 791 К, оп. 1, а.е. 24, л. 291-292.

29 Заповеди по Действующата армия. - Кюстендил, 1915. - № 85. - 15 ноем.

${ }^{30}$ Военни известия. - 1915. - № 145. - 16 ноем.

${ }^{31}$ Храм-паметник „Св. Александър Невски“. - София, 1924. - С. 36-38.

${ }^{32}$ Елдъров С. Българи, България, български съдби. - София, 2010. - С. 113 -124.

${ }^{33}$ Елдъров С. Денят на Независимостта... - С. 475.

${ }^{34}$ Народна отбрана. - 1926. - № 1277. - 6 май.

${ }^{35}$ Дневник. - 1922. - № 125. - 7 март.

${ }^{36}$ Шиимманов И. Дневник 1879-1927. - София, 2003. - С. 307.

37 Демократически сговор. - 1924. - № 125. - 4 март.

38 Празникът на Освобождението по страниците на българските вестници 1885-1944. - София, 2008.

39 Дьржавен вестник. - 1923. - № 267. - 28 февр.

40 Работническо дело. - 1945. - № 313. - 22 септ.

${ }^{41}$ Пак там. - 1945. - № 314. - 24 септ.

${ }^{42}$ Отечествен фронт. - 1950. - № 1652. - 5 ян.

${ }^{43}$ Работническо дело. - 1988. - № 245. - 1 септ.

${ }^{44}$ Пак там. - 1950. - № 54. - 23 февр.; № 55. - 24 февр.; 1952. - № 49. - 18 февр.; № 54. - 23 февр.

${ }^{45}$ Пак там. - 1952. - № 64. - 4 март; 1953. - № 62. - 3 март.

${ }^{46}$ Пак там. - 1958. - № 60. - 1 март; № 61. - 2 март; № 62. -3 март; № 63. - 4 март.

${ }^{47}$ Пак там. -1958 . - № 62. - 3 март.

48 Пак там. - 1990. - № 59. - 28 февр.

${ }^{49}$ Пак там. - 1990. - № 63. - 4 март.

${ }^{50}$ Демокрация. - 1991. - № 52 (318). - 2 март.

${ }^{51}$ Пак там. - 1993. - № 51 (937). - 4 март; № 53 (939). - 6 март; 1994. - № 51 (1243). - 2 март; № 52 (1244). - 5 март; 1995. - № 53 (1547). - 6 март; Дума. - 1993. - № 52. - 4 март; 1994. - № 52. 5-6 март; 1995. - № 52. - 2 март; № 53. - 4 март.

52 Демокрация. - 1997. - № 59 (2165). - 2 март.

53 Дума. - 1997. - № 51. - 3 март.

54 Демокрация. - 1998. - № 57 (2514). - 4 март; № 58 (2826). - 4 март; 2000. - № 60 (3206). 3 март; Дума. - 1998. - № 49. - 4 март; 2001. - № 53. - 5 март.

${ }_{55}^{5}$ Елдъров С. Денят на Независимостта... - С. 461-462.

${ }^{56}$ Демокрация. - 2002. - № 244. - 22 септ.

57 Дума. - 2003. - № 223. - 25 септ.

58 Пак там. - 2002. - № 52. -4 март.

${ }^{59}$ Пак там. - 2003. - № 51. - 3 март.

${ }^{60}$ Пак там. - 2003. - № 52. - 4 март. 